\title{
Some Notes on the Ideals and Goals of Indonesia's National Education System and the Inconsistency of its Implementation: A Comparative Analysis ${ }^{1}$
}

\author{
Soedijarto \\ Jakarta State University
}

\begin{abstract}
The Republic of Indonesia's State Constitution of 1945 adopted a basic policy that obliges the government to run one national education system. It would seem it was the belief of the Founding Fathers when they drafted the constitution that education would be the strategic vehicle for ensuring that the newly independent Indonesian nation would be modern, democratic, prosperous, and with a concept of social justice based on the state philosophy of Pancasila. In implementing the basic policy, a series of education laws (1950, 1954, 1989 and 2003) have been promulgated that were to produce an educated citizenry who would be 'intelligent, healthy, moral, democratic, and responsible'. This policy, and the goals and principles of education formulated in the constitution and in subsequent education laws, is in line with a paradigm followed by many nations that have made education an effective means of supporting their growth and development. Education is seen by some economists and political scientists to have a strategic role in improving the quality of life for Indonesian citizens. However, there has been no serious political determination on the part of the elites who control government and parliament to support the implementation of an education system that accords with the hopes and ambition of the Founding Fathers. The funding necessary for education has not been set aside in national budgets despite the constitutional and legislative requirements and expectations that this be done. The funding for education in Indonesia, compared with other developing nations, is low. The goals and principals adopted in the constitution and education laws have not been seriously and consistently implemented.
\end{abstract}

1 The original of this paper was presented on the occasion of the launching of 'Comparative Research and Policy Studies' at the Graduate School Program of the State University of Jakarta, 24 Nov 2008. 


\section{Introduction}

Indonesia is one of not so many nations whose constitution obliges the government to run one national educational system. More than that, as a consequence of the fourth amendment of its constitution, the state is obliged to assign at least 20 per cent of the national budget to education. As well, local government budgets are also required to support the needs of the education system. It is the writer's understanding that the reason the Indonesian Founding Fathers stressed the importance of education was to support the goal of building Indonesia as a nation that would be modern, democratic, prosperous, and socially just (mencerdaskan kehidupan bangsa) based on the state philosophy, the Pancasila.

However, after sixty-three years of independence, Indonesia's development in economics, science and technology, is still behind neighbouring countries that became independent decades after Indonesia. The question must be asked, What is wrong with the implementation of the Indonesian education system that it cannot contribute significantly to the progress of the nation? The great economists, from Adam Smith to Alfred Marshall to Henry Schultz, all postulated that a well-educated citizenry is essential for national development. Harbison and Myers (1965) stated more strongly that 'Indeed, if a country is unable to develop its human resources, it cannot build anything else, whether it be a modern political system, a sense of national unity, or a prosperous economy'. This contention by Harbison in 1965 was reasserted in 2004 by BPS-Statistics Indonesia, Bappenas and UNDP Indonesia (2004) in a report especially for Indonesia that

Indonesia must invest more in human development—not just to fulfil its people's basic rights but also to lay the foundations for economic growth and to ensure the long-term survival of its democracy. This investment is substantial but clearly affordable.

There can be little or no disagreement that developing human resources through education is necessary for national development. But the question then has to be asked; Why has the Indonesian education system so far not contributed significantly to the progress of Indonesia as a 
nation? To answer the question we need to conduct comparative studies to broaden our perception on how to run 'one national educational system' that is effective and relevant. This paper will try briefly to analyse the ideals and goals of Indonesia's national education system and its implementation.

\section{The Education System as an Integral Part of the Social System (Political, Economic, Social and Cultural) of a Nation}

Since 1950, through its education laws (of 1950, 1989, 2003), Indonesia has assumed that there are three dimensions to Indonesian education; intellectual, physical and moral. In the education law of 1950 it was stated that an educated Indonesian should be 'an intelligent, moral, responsible and democratic citizen'; in the education law of 1989, these ideals were expressed as 'belief in God the Almighty, having knowledge and skills, being healthy, physically and mentally, having a sound and self-confident personality, and having responsibility to the nation and society at large'; and in the education law of 2003, the stated outcome was to produce citizens who had a 'belief in God the Almighty and had high morality, good health, knowledge, intelligence, creativity, independence, and would be democratic and responsible citizens'.

Thus, it is clear, if our education system can produce educated citizens that have those characteristics, the writer is optimistic that the Indonesian national education system will be able to contribute to building an Indonesian nation that is modern, advanced, democratic and prosperous.

The next question is, What are the factors that will bring about an education system that is capable of producing graduates with those characteristics? In this regard, the writer subscribes to the paradigm that the outcome of education is in the form of graduate competence and this depends on the quality of education experienced by the learner. The quality of education depends on the educational resources (books, laboratories, learning materials, teachers, to name just a few). In turn, the supply of good quality educational facilities depends on the available 
funding from the national budget. The budget in turn is dependent on the policies of the polity. The flow can be illustrated in the following diagram.

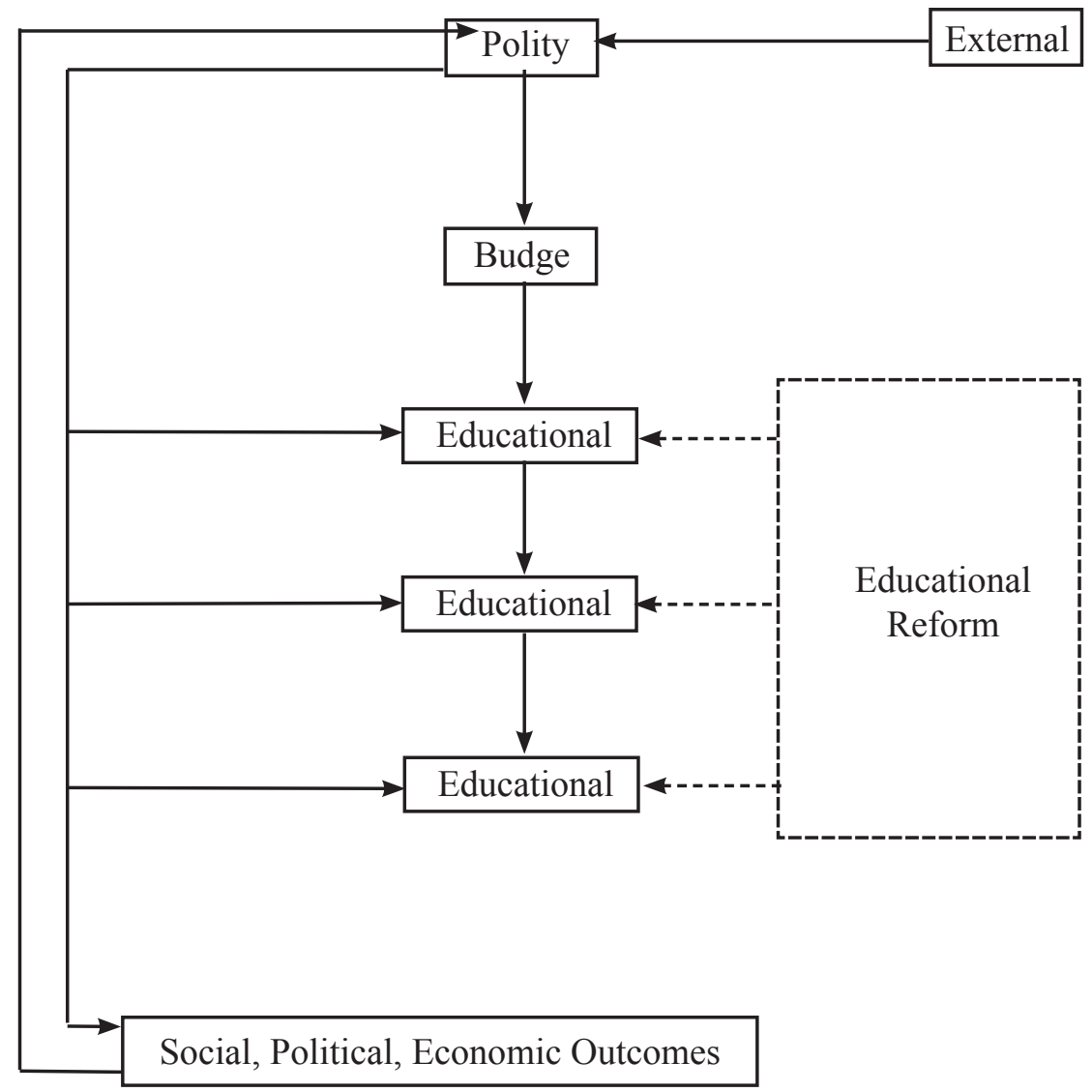

Diagram $1^{2}$

The problem that Indonesia faces is that budget allocations for education have never been adequate to provide educational resources to enable the education system to produce the outcomes it could and should. To illustrate the position of the Indonesian education budget, consider the following. In the year 2004, Indonesia was seen as a nation with an

2 Adapted from Carnowy and Levin (1976) 
education budget among the lowest of the developing nations, low even when compared with underdeveloped nations, in terms of its percentage of GDP. BPS-Statistics Indonesia, Bappenas and UNDP Indonesia (2004, p. 36) reported that

Indonesia's poor performance by international standards reflects a low level of investment. Indonesia spends around $1.5 \%$ of GDP on education, a proportion far lower than that in many Asian countries. The amount is relatively low as a proportion of government budget: in 2000/2001 Indonesia's proportion at $10 \%$ was significantly lower that Thailand's $30 \%$, Myanmar's 18\%, Bangladesh's 16\%, Nepal's 14\%, and Bhutan's 13\%.

Compared with other countries in the world, the figures are as follows: in the European Union, the average allocation is 5 per cent of GDP for education, except the Netherlands whose allocation in 1996 was 7 per cent of GDP (37 per cent of the national budget). Among Asian countries, Indonesia's allocation is the lowest at only 1.4 per cent of GDP. India's allocation is 5.2 per cent of GDP; Malaysia, 5.2 per cent; Thailand, 5.0 per cent; Vietnam, 2.8 per cent; the Philippines, 3.4 per cent; South Korea, 5.3 per cent and , Japan, 7 per cent of GDP. Although in 2009, after the Constitutional Court's verdict, it is planned to allocate 20 per cent of the national budget for education but this amount is to include teacher's salaries. The portion for the implementation of the education system is about Rp80 trillion, about 8 per cent of the national budget, still less than 2 per cent of GDP.

Why has Indonesia given such a low priority to funding for education when the constitution and the education laws have mandated so much more? The answer is that the polity (the government, parliament and political parties) seems unconcerned about the importance of education as an investment for building the nation. Since Soekarno, a leader who had the courage to stress the importance of having an adequate budget to support a national education system, there have been no more likeminded national leaders. This attitude is in direct contrast with Chinese leaders. Deng Xiaoping has stated (Li Lanqing, 2005, p. 15)

Leaders who neglect education lack vision and maturity, and they are 
unqualified to lead the drive for modernisation...we should try by every means to promote education, even if it means slowing down in other areas...however poor we are, we should give priority to funding education.

This basic attitude of Deng Xiaoping was reiterated by Prime Minister Jiang Zemin in an official statement when China started a program of education reform in 1993 (Li Lanqing, 2005). Jiang Zemin said

It is crucial that our economic development switches to a reliance on the advancement of science and technology and a better educated workforce, and that education is given strategic priority to raise the moral, scientific, and cultural standards of our entire nation.

This paper has intentionally quoted Chinese political leaders to exemplify that the quality of education is determined by the attitudes and understanding of the leadership of the polity. It would be very unusual for similar statements to emanate from the current Indonesian polity. To understand all the factors related to an education system, we need to ensure that the education system is an integral part of the social system of the nation. This can be seen in the following diagram (modified from the model by Carnowy and Levin (1976, p. 84).

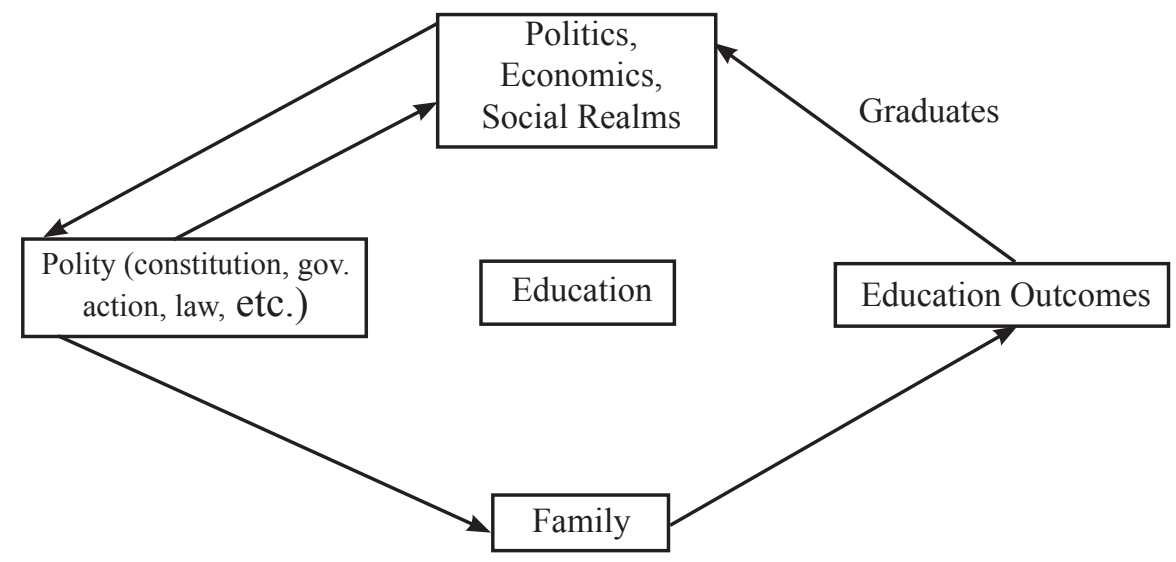

Diagram 2 
The diagram shows how education is influenced by the polity through the various policies that have an influence on the quality of education resources: budget policies and funding; and policies that affect the cultural, social and economic wellbeing of families. In turn, the polity is influenced by economics, the multiparty system, and diverse sociocultural realities. China can easily implement the ideas of its leadership, but Indonesia is still full of inconsistencies between the philosophy and policies, and between policies and implementation.

The further question is, What type of educational process is it that can produce graduates with competences and characteristics that will support the cultural transformation to a nation with a stable democracy and a prosperous economy? The next section will try to discuss this.

\section{Education as Culturisation}

History tells us that many developed countries, such as the United States of America (USA), the United Kingdom (UK), Japan and Germany, for example, have made education one of the instruments to achieve their goal of building a nation state. Those countries, to use the term coined by an education anthropologist, Yehudi Cohen (1970), have made schools the agents for building civilised states. Schools, to achieve this, have a role as centres for culturalisation. This school of thought was accepted by our Founding Fathers when they declared our independence and designed our constitution in 1945: in their words, mencerdaskan kehidupan bangsa and memajukan kebudayaan nasional, through the implementation of a single national education system. Unfortunately, in practice, Indonesian schools since independence have been little more than agents for transferring, copying, and memorising knowledge and with limited facilities. Strikingly, although there were many reforms in the 1970s, and since 1999 through National Basic State Policy promulgated by the Peoples Assembly (MPR), and in the education law 20 of 2003, which assigned to schools a role as centres for culturalisation in terms of competencies, attitudes and values, but even after these reforms our 
schools still act as the agents for transferring knowledge only. ${ }^{3}$

In the USA and the UK, to make their schools centres for culturalisation, the schools are supplied with adequate educational resources, such as libraries, laboratories, sports fields, qualified teachers and they are open from early in the morning to four o'clock in the afternoon. In such schools, the education of the children is based on what Unesco (1996) named the four pillars of education: learning to know, learning to do, learning to live together, and learning to be. Thus they (the learners), in school time, are not only doing academic learning in the classrooms but learning to live together (which includes the practices of democracy) as well as learning to do, that is, sport, music and the arts. In the USA, the dormitory school model, has been adopted at higher education levels; students in their first and second years are required to stay at a dormitory, which is supervised by the university. The US university campus has been called the 'city of intellect' by Clark Kerr (1963). Close to 90 per cent of the students stay in the campuses, which have a host of facilities, including various facilities for all branches of sport from track and field to horse riding.

This short illustration shows how these two developed countries have made schools agents of cultural transformation. According to Almond and Verba (1965), these two countries have reached the stage of inculcating a civic culture and, in the words of Seymour M Lipset (1963), stable democracy. According to the study by Almond and Verba (1965), of five countries (Italy, France, Germany, the USA and the UK), only the USA and the UK have achieved the stage of developing a civic culture.

When our Founding Fathers were still active in the administration of the nation, they provided universities with facilities to enable them to become academic communities. Each state university has student dormitories for men and for women and housing for faculty members. But unfortunately, they neglected primary and secondary schools as places to nurture community traditions.

3 It happened that this idea has been proposed by the present writer and Dr Muchtar Buchori as members of the Peoples Assembly. 
It is the present writer's view that, unless Indonesia can ensure that schools become centres of culturalisation as demanded by education law 20 of 2003, we cannot achieve the goal of building Indonesia as a nation that is modern, advanced, prosperous and democratic (cerdas kehidupannya, tinggi derajat kemakmurannya, dan maju kebudayaan nasionalnya) as defined by the Founding Fathers and stated in the preamble of Indonesia's constitution (UUD 1945). For this to happen, an education budget, at least 20 per cent of the national budget is needed. For ever.

Thus, it is important to be consistent in implementing all the principles enshrined by the constitution, by education laws, as well as government acts, especially with regard to national standards of education related to school facilities stated in government act 19 of 2005 . For it is only schools that have been provided with all necessary educational resources that can function as centres of culturalisation. Diagrammatically, the relations can be put as follows:
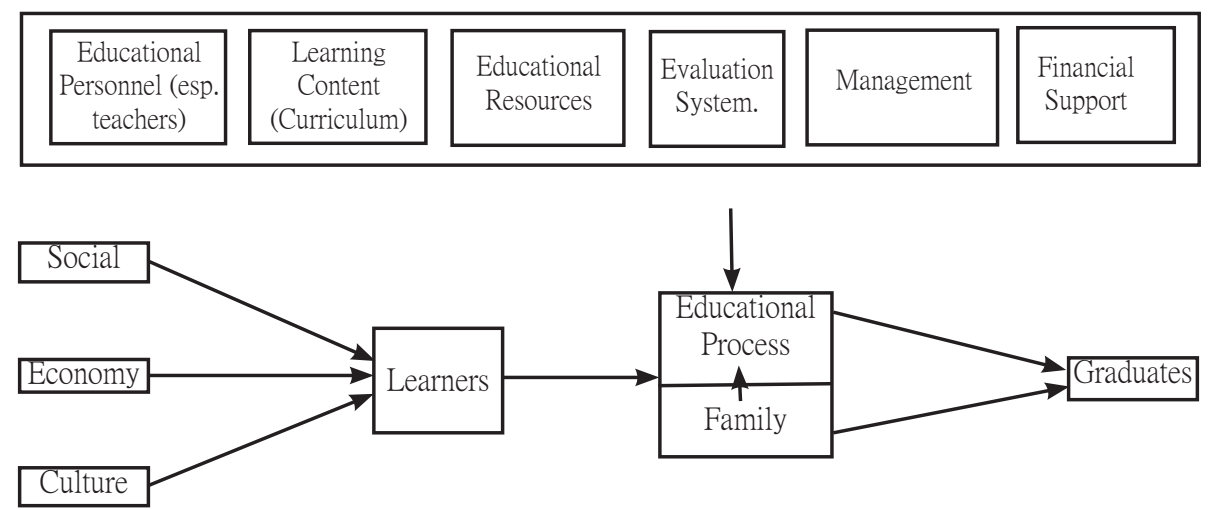

Diagram 3

From the diagram it can be seen that the quality of education and in turn its efficiency or effectiveness in promoting culturalisation is influenced, dependent even, on the availability of relevant educational resources; qualified and dedicated teachers, selected essential subject content, good pedagogical evaluation systems and adequate management and 
financial support. Because the learners are so heterogeneous in terms of socio-economic-cultural background and their aptitudes, talents, and interests influence their learning capability, the educational processes need to be designed to accommodate these characteristics. As well, the effect of the family's parenting model on their children's learning behaviour needs to be taken into consideration.

Thus, from the previous discussion it is clear how the educational process should be planned, developed, managed, and evaluated to be really relevant epistemologically, psychologically, as well as socially and morally, to mould the mind and characters of the learners.

As stated before, on paper, legally the Indonesian national education system is a solid foundation to implement education that will produce educated citizens who are competent and have characteristics as described in education law 20 of 2003 and supported by government act 19 of 2005 . The national education standards have been set but they must be supported by adequate resources and funding.

\section{Concluding Remarks}

From the foregoing discussion some conclusions can be generated.

1 That as an integral part of the social system of the nation, the Indonesia national education system has been given a role to contribute to building the nation state of Indonesia that has not been really meaningful.

2 That although all the principles adopted in the constitution, laws, and government acts were designed to support the implementation of a relevant and qualified education system, in practice those principles have not been consistently implemented.

3 That the failure of Indonesia's education system to contribute to building a nation state is because of the reluctance of the polity to find the political will to consistently and persistently implement the requirement of the constitution and the laws regarding education. 
4 Thus, compared with other countries that have had been successful in implementing educational system that support national development, Indonesia's leaders seem neglectful of the importance of education as the strategic vehicle to build the nation.

\section{References}

\section{Books}

Almond, GA and Verba, S (1965). The Civic Culture: Political Attitudes and Democracy in Five Nations. Boston: Little Brown.

BPS-Statistics Indonesia, Bappenas and UNDP Indonesia (2004). National Human Development Report 2004: the Economics of Democracy: Financing Human Development in Indonesia (2004). Jakarta: BPS-Statistics Indonesia, Bappenas and UNDP Indonesia.

Carnowy, M and Levin, Henry M (eds) (1976). The Limits of Educational Reform. New York: David McKay Co.

Cohen, Yehudi (1970). 'School and Civilization States' in Fischer, J (ed.). The Social Sciences and the Comparative Study of Educational Systems. Scranton: International Textbook Co.

Harbison, F and Myers, CA (1965). Manpower and Education: Country Studies in Economic Development. New York: McGraw-Hill.

Kerr, Clark (1963). The Uses of the University. Cambridge: Harvard University Press.

Li Lanqing, (2005). Education for 1.3 Billion: Former Chinese Vice Premier Li Lanqing on 10 Years of Education Reform and development. Hong Kong: Pearson Education Asia.

Lipset, Seymour M (1963). Political Man: the Social Bases of Politics. Garden City: Doubleday.

Malik Fajar, Undang-undang Republik Indonesia No. 20 Tahun 2003 Tentang Sistem Pendidikan Nasional (2006), Jakarta, Departemen Pendidikan Nasional RI.

MPR RI, Undang-undang Dasar Negara Republik Indonesia Tahun 1945 (2008), Jakarta, Sekretariat Jenderal MPR RI.

Soedijarto (2008). Landasan dan Arah Pendidikan Nasional Kita. Jakarta: Buku Kompas.

Unesco (1976). Learning, the Treasure Within: Report to UNESCO of the International Commission on Education for the Twenty-first Century. Paris: Unesco Publishing. 